\title{
Efficiency of boiling and four other methods for genomic DNA extraction of deteriorating spore-forming bacteria from milk
}

\section{Eficiência da fervura e outros quatro métodos para extração do DNA genômico de bactérias esporuladas deteriorantes do leite}

\author{
Jose Carlos Ribeiro Junior ${ }^{1 *}$; Ronaldo Tamanini²; Bruna Fritegoto Soares ${ }^{3}$; \\ Aline Marangon de Oliveira ${ }^{4}$; Fernando de Godoi Silva ${ }^{4}$; \\ Francine Fernandes da Silva ${ }^{4}$; Nayara Assis Augusto ${ }^{4}$; Vanerli Beloti ${ }^{5}$
}

\begin{abstract}
The spore-forming microbiota is mainly responsible for the deterioration of pasteurized milk with long shelf life in the United States. The identification of these microorganisms, using molecular tools, is of particular importance for the maintenance of the quality of milk. However, these molecular techniques are not only costly but also labor-intensive and time-consuming. The aim of this study was to compare the efficiency of boiling in conjunction with four other methods for the genomic DNA extraction of sporulated bacteria with proteolytic and lipolytic potential isolated from raw milk in the states of Paraná and Maranhão, Brazil. Protocols based on cellular lysis by enzymatic digestion, phenolic extraction, microwave-heating, as well as the use of guanidine isothiocyanate were used. This study proposes a method involving simple boiling for the extraction of genomic DNA from these microorganisms. Variations in the quality and yield of the extracted DNA among these methods were observed. However, both the cell lysis protocol by enzymatic digestion (commercial kit) and the simple boiling method proposed in this study yielded sufficient DNA for successfully carrying out the Polymerase Chain Reaction (PCR) of the rpoB and $16 S$ rRNA genes for all 11 strains of microorganisms tested. Other protocols failed to yield sufficient quantity and quality of DNA from all microorganisms tested, since only a few strains have showed positive results by PCR, thereby hindering the search for new microorganisms. Thus, the simple boiling method for DNA extraction from sporulated bacteria in spoiled milk showed the same efficacy as that of the commercial kit. Moreover, the method is inexpensive, easy to perform, and much less time-consuming.
\end{abstract}

Key words: Bacillus. Paenibacillus. PCR. Spores.

\section{Resumo}

A microbiota esporulada é a principal responsável pela deterioração do leite pasteurizado de longa vida útil nos Estados Unidos. A identificação destes micro-organismos é de especial importância para a qualidade do leite e ferramentas moleculares são fundamentais nesse processo. No entanto, exigem a execução de etapas onerosas e laboriosas que podem inviabilizar algumas pesquisas. O objetivo do presente trabalho foi comparar a eficiência do método de extração de DNA por fervura com outros quatro métodos para extração de DNA genômico de bactérias esporuladas com potencial proteolítico e

\footnotetext{
${ }^{1}$ Discente do Curso de Doutorado em Ciência Animal, Universidade Estadual de Londrina, UEL, Londrina, PR, Brasil. E-mail: jcribeiro.vet@hotmail.com

2 Dr. em Ciência Animal, UEL, Londrina, PR, Brasil. E-mail: ronaldot@uel.br

${ }^{3}$ Discente do Curso de Graduação em Medicina Veterinária, Bolsista de Iniciação Científica, UEL, Londrina, PR, Brasil. E-mail: brufrite@gmail.com

${ }^{4}$ Médicos Veterinários, Residentes em Inspeção de Leite e Derivados, UEL, Londrina, PR, Brasil. E-mail: lipoa.uel@gmail.com; francinefvet@hotmail.com

5 Prof $^{\mathrm{a}} \mathrm{Dr}^{\mathrm{a}}$, Departamento de Medicina Veterinária Preventiva, UEL, Londrina, PR, Brasil. E-mail: vbeloti@uel.br

* Author for correspondence
} 
lipolítico isoladas do leite cru dos estados do Paraná e Maranhão, Brasil. Foram utilizados protocolos que se baseavam na lise celular por digestão enzimática, agitação com fenol, aquecimento em microondas, tiocianato de guanidina e este trabalho propõe um método por fervura simples para o estudo desses micro-organismos. Observaram-se variações nos métodos de quantificação do DNA extraído e baixo coeficiente de correlação de Person entre esses métodos. No entanto, observou-se que tanto no protocolo de lise celular por digestão enzimática (kit comercial) quanto na fervura simples proposta pelo presente estudo, houve êxito na realização da Reação em Cadeia da Polimerase (PCR) para pesquisa dos genes rpoB e $16 S$ rRNA para todas as 11 cepas de micro-organismos testadas. Os outros protocolos não apresentaram sucesso na extração de DNA para a totalidade da microbiota avaliada, já que somente algumas amostras tiveram êxito nas reações de PCR, fato que os inviabiliza para a pesquisa desses micro-organismos. Dessa forma, o método de fervura simples das suspensões de bactérias esporuladas deteriorantes do leite demonstrou a mesma eficiência do kit comercial para a extração do DNA desses micro-organismos, sendo um método de baixo custo e de fácil e rápida execução.

Palavras-chave: Bacillus. Esporos. Paenibacillus. PCR.

\section{Introduction}

Several studies have shown that part of the spore-forming microbiota of raw milk are primarily composed of Bacillus, Paenibacillus (HUCK et al., 2007) and genera thereof, following reclassification. These spore-forming bacteria are capable of withstanding pasteurization (BUEHNER et al., 2014) and Ultra High Temperature (UHT) treatments (ESPEJO et al., 2014). These have been described as the major group of microorganisms responsible for reducing the shelf life of pasteurized milk in the United States (HUCK et al., 2007).

A preliminary Brazilian study showed that some microorganisms derived from germination of spores in milk exhibited deteriorating activity, due to their proteolytic and/or lipolytic activity (RIBEIRO JÚNIOR et al., 2016), thereby affecting the shelflife and sensory characteristics of pasteurized milk and dairy products (BELOTI, 2015).

Molecular methods for identification and characterization of microorganisms are modern tools that allow for checking not only the composition and diversity of microbiota in milk (FUQUAY et al., 2011), but also genomic variations within the same species (BECKER et al., 2014), production of toxins (CHIEFARI et al., 2015), spoilage (SCATAMBURLO et al., 2015) and pathogenic (REDDY et al., 2016) potential. However, these methods are labor-intensive, time-consuming, and often costly.
The great diversity of microorganisms that compose the food microbiota is a limiting factor for the use of certain molecular methods. Some microorganisms require the execution of specific steps for genomic analysis, such as in cellular DNA extraction. It is known that simply boiling a suspension of Escherichia coli (MARTINS et al., 2015) or Salmonella spp. (ALVES et al., 2012), for example, is an effective method for inducing cellular lysis, for carrying out Polymerase Chain Reactions (PCR). However, for Gram-positive microorganisms, such as some Bacillus spp., specific methods must be carried out for DNA extraction.

Considering the importance of deteriorating spore-forming microbiota in milk and the use of molecular tools for identification and microbial characterization, the aim of present study was to verify the efficacy of boiling and four other methods for genomic DNA extraction of spore-forming bacteria that, previously, showed deteriorating activity.

\section{Material and Methods}

\section{Selection of strains}

Different strains of spore-forming bacteria were previously isolated from milk after heat treatment $\left(80 \pm 0.5{ }^{\circ} \mathrm{C}\right.$ for 12 minutes), according to the technique for aerobic spore count described in Standard Methods for Examination of Dairy 
Products (FRANK; YOUSEF, 2004). These strains were identified by partial sequencing of the $16 \mathrm{~S}$ $r R N A$ gene.

The proteolytic and lipolytic potential of each isolate were verified by plating the colony on milk agar and tributyrin agar, respectively. The strains and their respective spoilage activity are described in Table 1. Bacillus sporothermodurans strain does not exhibit any deteriorating activity. However, it was included in the study as it had been isolated from spore-forming microbiota of Brazilian UHT milk (PEREIRA et al., 2013).

Table 1. Strains of spore-forming bacteria from Brazilian raw milk.

\begin{tabular}{|c|c|c|c|}
\hline Strains & $\begin{array}{l}\text { 16S rRNA GenBank } \\
\text { accession number }\end{array}$ & Spoilage potential & $\begin{array}{c}\text { Brazilian state of } \\
\text { isolation }\end{array}$ \\
\hline $\begin{array}{l}\text { Bacillus sp. LIPOA/ } \\
\text { UEL_83 }\end{array}$ & KU377295 & Proteolytic and Lipolytic & Paraná \\
\hline $\begin{array}{l}\text { Lysinibacillus massiliensis } \\
\text { strain LIPOA/UEL_23 }\end{array}$ & KT748553 & Lipolytic & Maranhão \\
\hline $\begin{array}{l}\text { Bacillus licheniformis } \\
\text { strain LIPOA/UEL_1 }{ }^{B}\end{array}$ & KP713760 & Proteolytic and Lipolytic & Paraná \\
\hline $\begin{array}{l}\text { Bacillus sp. LIPOA/ } \\
\text { UEL_86 }{ }^{B}\end{array}$ & KU377296 & Proteolytic and Lipolytic & Paraná \\
\hline $\begin{array}{l}\text { Bacillus } \\
\text { sporothermodurans strain } \\
\text { LIPOA/UEL_87 }\end{array}$ & KU377297 & - & Paraná \\
\hline $\begin{array}{l}\text { Bacillus pumilus strain } \\
\text { LIPOA/UEL_4 }\end{array}$ & KP713763 & Proteolytic and Lipolytic & Paraná \\
\hline $\begin{array}{l}\text { Paenibacillus sp. LIPOA/ } \\
\text { UEL_7 }\end{array}$ & KP713766 & Lipolytic & Paraná \\
\hline $\begin{array}{l}\text { Paenibacillus sp. LIPOA/ } \\
\text { UEL_8 } 8\end{array}$ & KU377298 & Lipolytic & Paraná \\
\hline $\begin{array}{l}\text { Bacillus circulans strain } \\
\text { LIPOA/UEL_6 }\end{array}$ & KP713765 & Lipolytic & Paraná \\
\hline $\begin{array}{l}\text { Bacillus licheniformis } \\
\text { strain LIPOA/UEL_3 } 3^{A}\end{array}$ & KP713762 & Proteolytic and Lipolytic & Paraná \\
\hline $\begin{array}{l}\text { Brevibacillus borstelensis } \\
\text { strain LIPOA/UEL_29 }\end{array}$ & KT784818 & Proteolytic and Lipolytic & Maranhão \\
\hline
\end{tabular}

${ }^{\mathrm{A}}$ Hemolytic strain on sheep blood agar

${ }^{\mathrm{B}}$ No hemolytic strain

\section{DNA extraction protocols}

The strains were grown in Brain Heart Infusion Broth (BHI) for 48 hours at $35^{\circ} \mathrm{C}$, distributed in 1-ml aliquots into microfuge tubes, and centrifuged for 5 minutes at 14,000 rpm. An estimated concentration of each microorganism after the incubation period

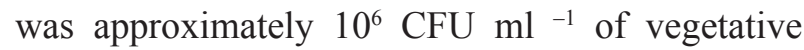
forms. The supernatant was discarded and the pellets were subjected to DNA extraction protocols.

Five bacterial DNA extraction protocols (A-E) used for microorganisms were compared; these are described in Table 2. The extraction method A, which was a commercial kit, gDNA ChargeSwitch ${ }^{\circledR}$ Bacteria Mini Kit (Invitrogen, Carlsbad, CA, USA) was used as standard. 
Table 2. DNA extraction methods.

\begin{tabular}{ccc}
\hline Method & Principle of the cellular lysis & Reference \\
\hline$A$ & Enzymatic digestion & $\begin{array}{c}\text { ChargeSwitch }^{\circledR} \text { gDNA Mini Bacteria Kit } \\
\text { (Invitrogen, Carlsbad, CA, USA) }\end{array}$ \\
$B$ & Boiling & This study \\
$C$ & Shaking with pure phenol & Cheng and Jiang (2006) \\
$D$ & Microwave heating & Bollet et al. (1991) \\
$E$ & Guanidine isothiocyanate & Boom et al. (1990) \\
\hline
\end{tabular}

This work proposes method B, i.e. cell lysis by simple boiling. Briefly, the bacterial pellets were suspended in $200 \mu \mathrm{l}$ of TE buffer (Tris-HCl [10 $\mathrm{mM}$ ]: EDTA [1 $\mathrm{mM}]$ ) and subjected to 15 minutes of boiling. Immediately after boiling, the microfuge tubes were placed in an ice bath for 15 minutes and then centrifuged for 5 minutes at 14,000 rpm at room temperature. The supernatant containing DNA $(100 \mu \mathrm{l})$ was transferred to another clean tube and stored at $-20^{\circ} \mathrm{C}$.

Quantification and quality assessment of DNA extraction products

Quantification of DNA extracted by different methods was performed spectrophotometrically (NanoDrop ND-2000 Spectrophotometer, NanoDrop Technologies, Wilmington, DE, USA), and the quality of the extracted DNA was estimated from the ratio of absorbance at 260 and $280 \mathrm{~nm}$. A value of 1.8 was considered to indicate pure DNA.
All extraction of products was also quantified by Qubit $^{\circledR}$ dsDNA HS Assay Kit (Invitrogen, Carlsbad, CA, USA) which is not influenced by the presence of residual reactants and interfering chemicals. At this stage, the samples that gave a reading of "too low" were considered $0 \mathrm{ng} \mu \mathrm{l}^{-1}$ for quantification.

\section{PCR Assays}

The extracted DNA was subjected to PCR, which partially amplified the rроB gene, as described by Durak et al. (2006). This gene allows for better identification and characterization of spore-forming microorganisms in milk.

In addition, DNA samples taken from protocol A and $\mathrm{B}$ the commercial kit and boiling were subjected to PCR amplification of the $16 S$ rRNA gene, which is widely used for sequencing and identification of bacteria. The primers and conditions for each assay are described in Table 3.

Table 3. Primers and PCR cycling conditions of genes rpoB and $16 S$ rRNA.

\begin{tabular}{|c|c|c|c|c|}
\hline Gene & Primers (5' - 3') & $\begin{array}{l}\text { Size } \\
\text { (pb) }\end{array}$ & PCR cycling conditions & Reference \\
\hline rpoB & $\begin{array}{l}\text { AARYTIGGMCCTGAAGAAAT } \\
\text { TGIARTTTRTCATCAACCATGTG }\end{array}$ & 740 & $\begin{array}{c}94^{\circ} \mathrm{C}-3 \mathrm{~min} \\
20 \mathrm{x}\left(94^{\circ} \mathrm{C}-30 \mathrm{seg}, \mathrm{TD}^{\mathrm{a}}-30 \mathrm{seg}, 72^{\circ} \mathrm{C}-1 \mathrm{~min}\right) \\
20 \mathrm{x}\left(94^{\circ} \mathrm{C}-1 \mathrm{~min}, 50-30 \mathrm{seg}, 72^{\circ} \mathrm{C}-1 \mathrm{~min}\right) \\
72^{\circ} \mathrm{C}-7 \mathrm{~min}\end{array}$ & Drancourt et al. (2004) \\
\hline $16 S r R N A$ & $\begin{array}{l}\text { GAGTTTGATCMTGGCTCAG } \\
\text { GGYTACCTTGTTACGACTT }\end{array}$ & 1465 & $\begin{array}{c}94^{\circ} \mathrm{C}-5 \mathrm{~min} \\
35 \mathrm{x}\left(94^{\circ} \mathrm{C}-1 \mathrm{~min}, 58^{\circ} \mathrm{C}-1 \mathrm{~min}, 72^{\circ} \mathrm{C}-1 \mathrm{~min}\right) \\
72^{\circ} \mathrm{C}-10 \mathrm{~min}\end{array}$ & Osborne et al. (2005) \\
\hline
\end{tabular}

aTouchdown PCR from $60^{\circ} \mathrm{C}$ to $50^{\circ} \mathrm{C}$ with temperature decrease of $0.5^{\circ} \mathrm{C}$ per cycle. 
The PCR was performed with approximately 50 ng DNA template, $100 \mathrm{nM}$ of each deoxynucleotides, $5 \mu 110 \mathrm{X}$ buffer, $75 \mathrm{mmol} \mathrm{L}^{-1} \mathrm{MgCl}_{2}, 20 \mathrm{pmol} \mathrm{L}^{-1}$ of each primer and $2.5 \mathrm{U}$ of Platinum Taq DNA polymerase (Invitrogen, Carlsbad, CA, USA).

Amplification was performed in a thermocycler (Aeris $^{\mathrm{TM}}$ Thermal Cycler, Esco ${ }^{\circledR}$ Micro Pte. Ltd., Singapore) and the PCR amplified DNA samples were applied to $1 \%$ agarose gel (Invitrogen, Carlsbad, CA, USA) and subjected to electrophoresis for 1 hour at a constant voltage of $90 \mathrm{~V}$. The gels were stained with ethidium bromide solution at $0.2 \mathrm{mg} \mathrm{ml}^{-1}$ for 20 minutes and visualized in UV transilluminator.

\section{Statistical analysis}

The Pearson's correlation coefficient between the DNA quantification methods was performed in Statistica software v. 6.0 (StatSoft, OK, USA).

\section{Results and Discussion}

The yield and quality of the extracted DNA by different methods is presented in Table 4. Large differences could be observed in both quantitative methods and the different DNA extraction protocols evaluated here.

Table 4. Quantification and quality of genomic DNA from spore-forming bacterial strains after different DNA extraction methods.

\begin{tabular}{|c|c|c|c|c|c|}
\hline $\begin{array}{c}\text { Extraction } \\
\text { method }\end{array}$ & & $\begin{array}{c}\text { Qubit }^{\circledR} \text { DNA } \\
\text { quantification }(\mathrm{ng} / \mu \mathrm{L})\end{array}$ & $\begin{array}{c}\text { NanoDrop }{ }^{\circledR} \text { DNA } \\
\text { quantification }(\mathrm{ng} / \mu \mathrm{L})\end{array}$ & $260 / 280$ & $\mathbf{C C}^{\mathrm{b}}$ \\
\hline \multirow{3}{*}{$\begin{array}{l}\text { Enzymatic } \\
\text { digestion }^{1}\end{array}$} & Mean $\left( \pm \mathrm{SD}^{\mathrm{a}}\right)$ & $13.4(10.6)$ & $105.7(121.4)$ & $1.9(0.2)$ & \multirow{3}{*}{-0.2} \\
\hline & Maximum & 33.3 & 406.3 & 2.1 & \\
\hline & Minimum & 0.0 & 7.1 & 1.5 & \\
\hline \multirow{3}{*}{ Boiling $^{2}$} & Mean $\left( \pm \mathrm{SD}^{\mathrm{a}}\right)$ & $4.2(5.7)$ & $105.7(38.3)$ & $1.4(0.7)$ & \multirow{3}{*}{0} \\
\hline & Maximum & 20.6 & 196.4 & 1.7 & \\
\hline & Minimum & 1.1 & 66.8 & -0.7 & \\
\hline \multirow{3}{*}{$\begin{array}{l}\text { Shaking with } \\
\text { pure phenol }^{3}\end{array}$} & Mean $\left( \pm \mathrm{SD}^{\mathrm{a}}\right)$ & $2.3(2.5)$ & $873.3(118.9)$ & $1.5(0.1)$ & \multirow{3}{*}{-0.1} \\
\hline & Maximum & 7.8 & 1091.3 & 1.8 & \\
\hline & Minimum & 0.0 & 604.3 & 1.5 & \\
\hline \multirow{3}{*}{$\begin{array}{l}\text { Microwave } \\
\text { heating }^{4}\end{array}$} & Mean $\left( \pm \mathrm{SD}^{\mathrm{a}}\right)$ & $0.1(0.1)$ & $415.3(510.4)$ & $1.5(0.1)$ & \multirow{3}{*}{-0.1} \\
\hline & Maximum & 0.4 & 1263.8 & 1.8 & \\
\hline & Minimum & 0.0 & 27.7 & 1.4 & \\
\hline \multirow{3}{*}{$\begin{array}{l}\text { Guanidine } \\
\text { isothiocyanate }\end{array}$} & Mean $\left( \pm \mathrm{SD}^{\mathrm{a}}\right)$ & $14.3(14.4)$ & $50.5(44.6)$ & $1.8(0.2)$ & \multirow{3}{*}{0.7} \\
\hline & Maximum & 41.9 & 156.9 & 2.1 & \\
\hline & Minimum & 1.6 & 15.2 & 1.6 & \\
\hline
\end{tabular}

${ }^{\mathrm{a}} \mathrm{SD}=$ Standard derivation; ${ }^{\mathrm{b}} \mathrm{CC}=$ Coefficient correlation between the methods of genomic DNA quantification ${ }^{1}$ ChargeSwitch $^{\circledR}$ gDNA Mini Bacteria Kit (Invitrogen, Carlsbad, CA, USA); ${ }^{2}$ This study; ${ }^{3}$ Cheng and Jiang (2006); ${ }^{4}$ Bollet et al. (1991); ${ }^{5}$ Boom et al. (1990).

The absorbance readings can be changed by phenolic residues and/or chloroform, carbohydrates, proteins, and guanidine isothiocyanate, among others (CHENG; JIANG, 2006). Thus, DNA extraction methods involving purification steps are generally subject to spectrophotometric changes (Figure 1) that interfere with quantification, consequently affecting the $260 / 280$ ratio, as was seen for methods B, C and D (Table 4). Precipitation and elution of DNA used in the methods A and B removed the interference of extraction matrix that led to lower spectrophotometric changes. However, the DNA purification step is not a limiting factor for the execution of PCR assay. 
Figure 1. gDNA absorbance spectrums of spore forming bacteria extracted by methods ChargeSwitch ${ }^{\circledR}$ gDNA Mini Bacteria Kit (Invitrogen, Carlsbad, CA, USA) (A), boiling (this study) (B), Cheng e Jiang (2006) (C), Bollet et al. (1991) (D) and Boom et al. (1990) (E).

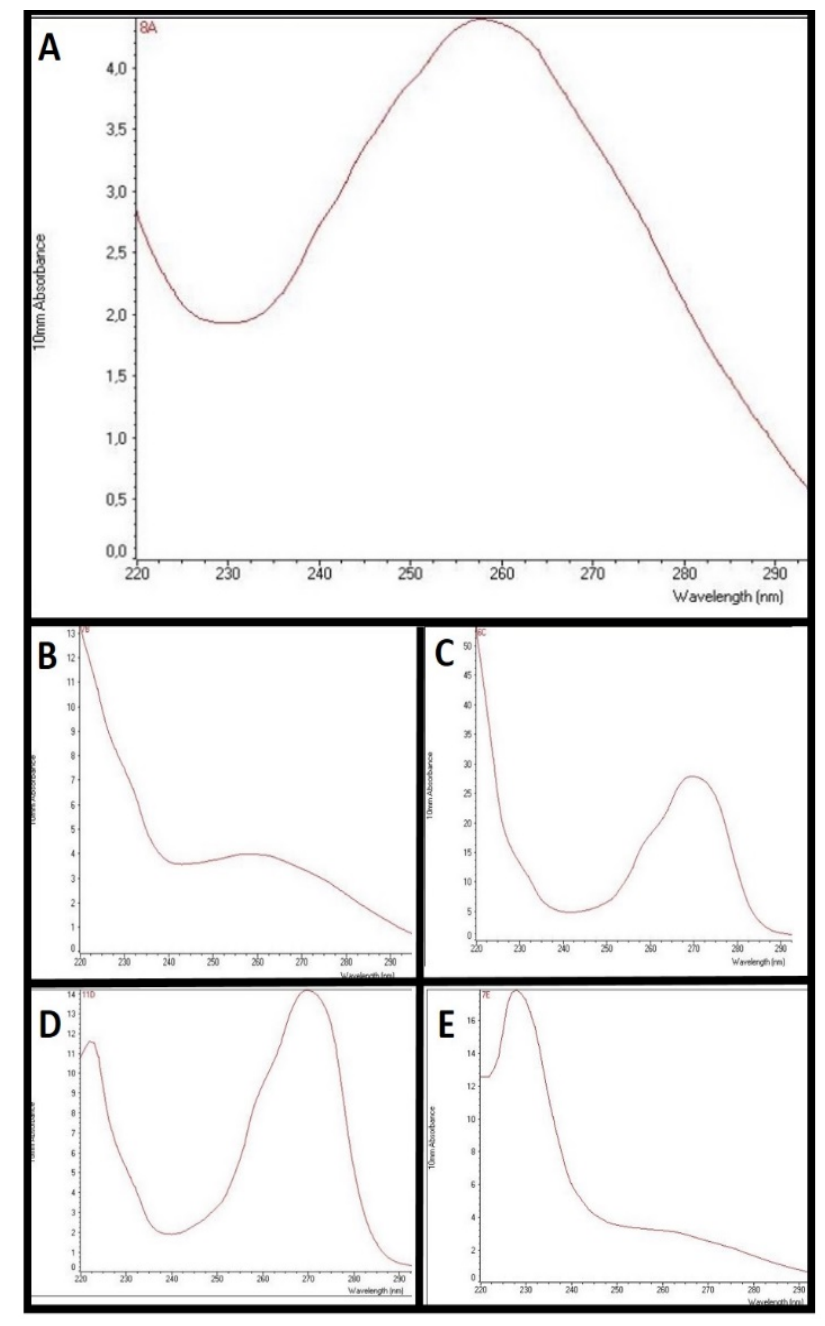

Table 4 shows the low coefficient of correlation between the methods of quantification of DNA, indicating that the quantification method can directly influence the PCR, since predetermined amounts of DNA template must be used in the reaction.

The same samples, where quantification showed near zero values in Qubit ${ }^{\circledR}$ (too low), showed positive results in the PCR for both genes in extraction protocols A and B (Figures 2 and 3). Thus, even at low quantities of DNA, the sensitivity of PCR is high enough to produce a satisfactory amount of amplicons for sequencing and further analysis, such as Restriction Fragment Length Polymorphism (RFLP), for example.

Considering the PCR results, it was observed that samples extracted by method A and B [gDNA ChargeSwitch $^{\circledR}$ Bacteria Mini Kit (Invitrogen, Carlsbad, CA, USA) and simple boiling], respectively, consistently showed similar results, both for the $r p o B$ gene (Figure 2), as well as the $16 \mathrm{~S}$ $r R N A$ (Figure 3), in all samples tested. The methods $\mathrm{C}, \mathrm{D}$ and $\mathrm{E}$ were not effective in extracting DNA from total sporulated microorganisms, as evidenced by amplification of the $r p o B$ gene (Figure 4). 
Figure 2. PCR results of $r p o B(740 \mathrm{pb})$ gene of strains from spore forming microbiota of the milk extract by commercial kit (A) (Invitrogen, CA, USA) and boiling (B) propose of this work. Line 1: DNA ladder; 2: Bacillus sp. LIPOA/ UEL_83; 3: Lysinibacillus massiliensis strain LIPOA/UEL_23; 4: Bacillus licheniformis strain LIPOA/UEL_1; 5: Bacillus sp. LIPOA/UEL_86; 6: Bacillus sporothermodurans strain LIPOA/UEL_87; 7: Bacillus pumilus strain LIPOA/UEL_4; 8: Paenibacillus sp. LIPOA/UEL_7; 9: Paenibacillus sp. LIPOA/UEL_88; 10: Bacillus circulans strain LIPOA/UEL_6; 11: Bacillus licheniformis strain LIPOA/UEL_3; 12: Brevibacillus borstelensis strain LIPOA/ UEL_29; 13: Negative control.

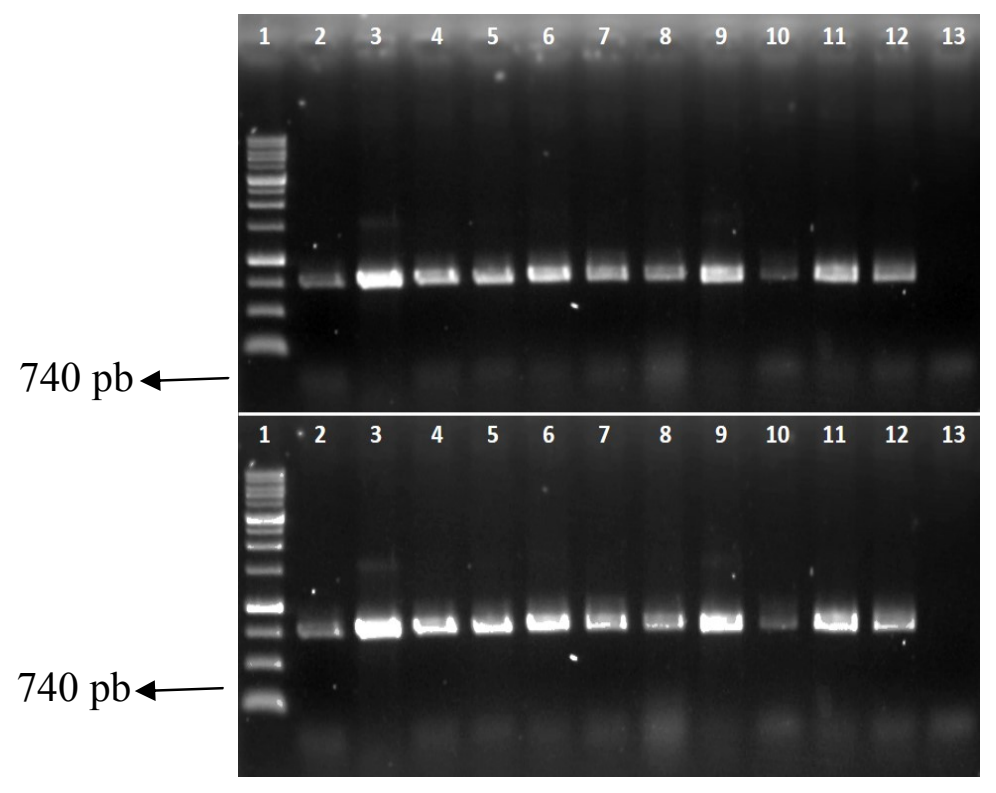

Figure 3. PCR results of $16 S \operatorname{rRNA}(1465 \mathrm{pb})$ gene of strains from spore forming microbiota of the milk extract by commercial kit (A) (Invitrogen, CA, USA) and boiling (B) propose of this work. Line 1: DNA ladder; 2: Bacillus sp. LIPOA/UEL_83; 3: Lysinibacillus massiliensis strain LIPOA/UEL_23; 4: Bacillus licheniformis strain LIPOA/ UEL_1; 5: Bacillus sp. LIPOA/UEL_86; 6: Bacillus sporothermodurans strain LIPOA/UEL_87; 7: Bacillus pumilus strain LIPOA/UEL_4; 8: Paenibacillus sp. LIPOA/UEL_7; 9: Paenibacillus sp. LIPOA/UEL_88; 10: Bacillus circulans strain LIPOA/UEL_6; 11: Bacillus licheniformis strain LIPOA/UEL_3; 12: Brevibacillus borstelensis strain LIPOA/UEL_29; 13: Negative control.

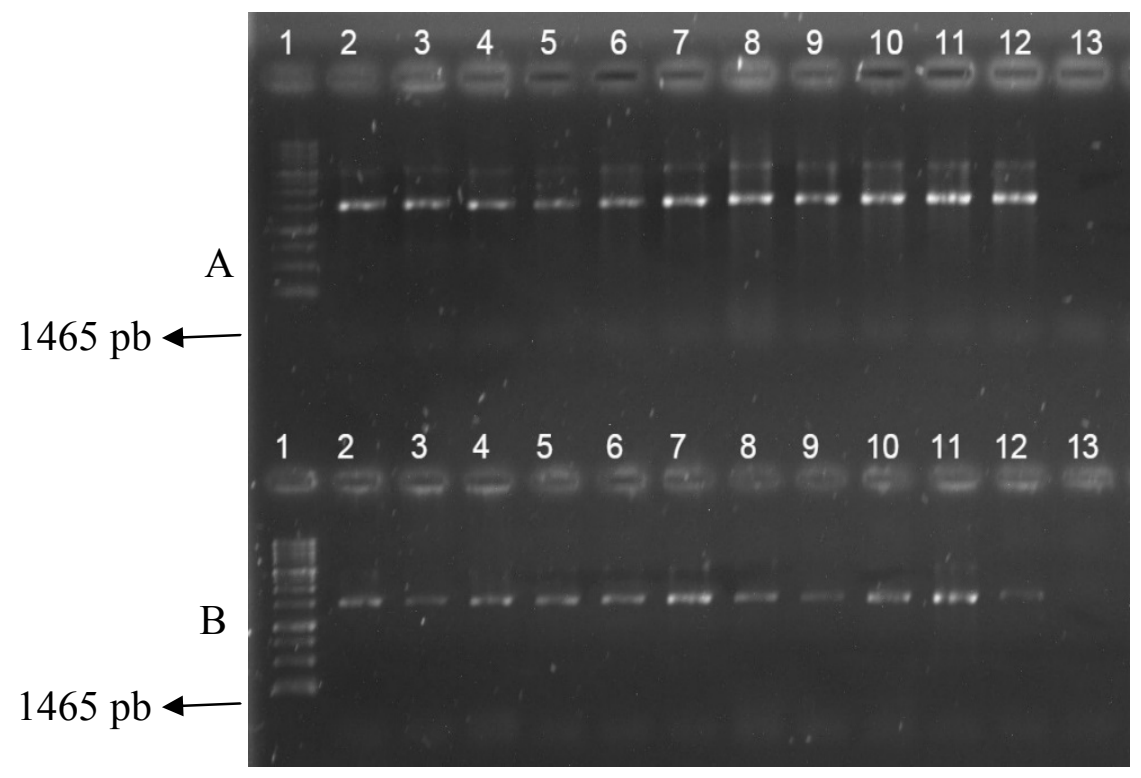


Figure 4. PCR results of rpoB (740pb) gene of strains of spore forming microbiota from milk extract by methods with shaking with pure phenol (CHENG; JIANG, 2006) (C), microwave heating (BOLLET et al., 1991) (D) and guanidine isothiocyanate (BOOM et al., 1990) (E). Line 1: DNA ladder; 2: Bacillus sp. LIPOA/UEL_83; 3: Lysinibacillus massiliensis strain LIPOA/UEL_23; 4: Bacillus licheniformis strain LIPOA/UEL_1; 5: Bacillus sp. LIPOA/UEL_86; 6: Bacillus sporothermodurans strain LIPOA/UEL_87; 7: Bacillus pumilus strain LIPOA/UEL_4; 8: Paenibacillus $s p$. LIPOA/UEL_7; 9: Paenibacillus sp. LIPOA/UEL_88; 10: Bacillus circulans strain LIPOA/UEL_6; 11: Bacillus licheniformis strain LIPOA/UEL_3; 12: Brevibacillus borstelensis strain LIPOA/UEL_29; 13: Negative control.

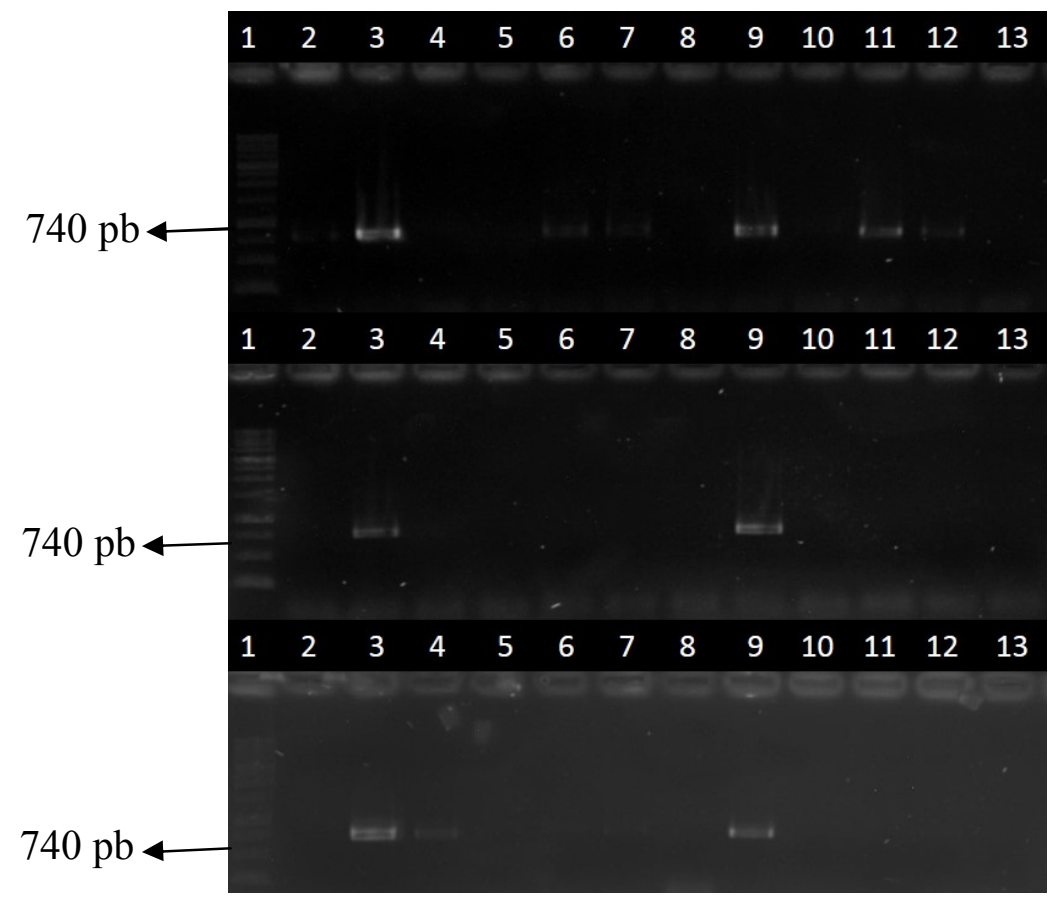

Ahmed et al. (2014), after comparing methods C and D for Gram-positive (Staphylococcus aureus) and Gram-negative bacteria, concluded that the lysis method by microwave showed better performance in the recovery of DNA. However, the present study demonstrated the limitations of these two methods in extracting gDNA from spore- forming bacteria in milk. Moreover, these methods are time consuming and require high quantities of inputs in relation to the method B, proposed in this study.

The extraction method based on cellular lysis with guanidine isothiocyanate (BOOM et al., 1990) (E) showed the best ratio 260/280 with respect to the purity of DNA obtained and the best Pearson's correlation coefficient between the quantification methods. However, the results of the PCR (Figure 4) indicate that the method was not capable of extracting DNA from all milk deteriorating spore- forming microbiota, being effective only for Lysinibacillus massiliensis, Bacillus licheniformis, and Paenibacillus spp., among those tested. Futhermore, the method involves multiple steps and reagents and it is more expensive and time consuming.

This may be related to the composition of the cell wall of Gram-positive microorganisms of spore-forming microbiota of milk, which has peptidoglycan responsible for increased rigidity to the wall of Gram-negative microorganisms (FUQUAY et al., 2011) that easily have their cell walls disrupted by boiling (MARTINS et al., 2015).

It was observed that for Gram-positive bacteria that comprise the milk- deteriorating spore-forming bacteria, boiling was sufficient for DNA extraction and PCR amplification of both $16 S$ rRNA and $r p o B$ 
genes. As the method is fast, cheap, and easy to perform, the boiling of suspensions of spore-forming microbiota from milk is an effective method for molecular studies of these microorganisms.

\section{Conclusion}

The DNA extraction by boiling proposed in this work was as efficient as the commercial kit for the PCR detection of rpoB and 16S rRNA genes of all the spoilage microorganisms evaluated.

The other gDNA extraction protocols evaluated were found to be ineffective. Thus, the simple boiling method of spoilage bacteria sporulated suspension is an important alternative for carrying out molecular studies of this microbiota, since it is as efficient as the commercial kit, but much less costly and laborious.

\section{References}

AHMED, O. B.; ASGHAR, A. H.; ELHASSAN, M. M. Comparison of three DNA extraction methods for polymerase chain reaction (PCR) analysis of bacterial genomic DNA. African Journal of Microbiology Research, Giza, v. 8, n. 6, p. 598-602, 2014.

ALVES, J.; MARQUES, V. V.; PEREIRA, L. F. P.; HIROOKA, E. Y.; OLIVEIRA, T. C. R. M. Multiplex PCR for the detection of Campylobacter spp. and Salmonella spp. in chicken meat. Journal of Food Safety, Weinheim, v. 32, n. 3, p. 345-350, 2012.

BECKER, K.; BALLHAUSEN, B.; KÖCK, R.; KRIEGESKORTE, A. Methicillin resistance in Staphylococcus isolates: The mec alphabet with specific consideration of mecC, a mec homolog associated with zoonotic S. aureus lineages. International Journal of Medical Microbiology, Hannover, v. 304, n. 7, p. 794804, 2014.

BELOTI, V. Leite: obtenção, inspeção e qualidade. Londrina: Editora Planta, 2015. 417 p.

BOLLET, C.; GEVAUDAN, M. J.; LAMBALLERIE, X.; ZANDOTTI, C.; MICCO, P. A simple method for the isolation of chromosomal DNA from Gram positive or acid-fast bacteria. Nucleic Acids Research, Oxford, v. 19, n. 8, p. $1955,1991$.
BOOM, R.; SOL, J. S.; SALIMANS, M. M.; JANSEN, C. L.; WERTHEIM-VAN, P. M.; NOORDA, J. Rapid and simple method for purification of nucleic acids. Journal of Clinical Microbiology, Barcelona, v. 28, n. 3, p. 495503, 1990.

BUEHNER, K. P.; ANAND, S.; GARCIA, A. Prevalence of thermoduric bacteria and spores on 10 midwest dairy farms. Journal of Dairy Science, Madison, v. 97, n. 12, p. 6777-6784, 2014.

CHENG, H. R.; JIANG, N. Extremely rapid extraction of DNA from bacteria and yeasts. Biotechnology Letters, Chicago, v. 28, n. 1, p. 55-59, 2006.

CHIEFARI, A. K.; PERRY, M. J.; KELLY-CIRINO, C.; EGAN, C. T. Detection of Staphylococcus aureus enterotoxin production genes from patient samples using an automated extraction platform and multiplex real-time PCR. Molecular and Cellular Probes, Bochum, v. 29, n. 6, p. 461-467, 2015.

DRANCOURT, M.; ROUX, V.; FOURNIER, P. E.; RAOULT, D. rpoB gene sequence-based identification of aerobic gram-positive cocci of the genera Streptococcus, Enterococcus, Gemella, Abiotrophia, and Granulicatella. Journal of Clinical Microbiology, Barcelona, v. 42, n. 2, p. 497-504, 2004.

DURAK, M. Z.; FROMM, H. I.; HUCK, J. R.; ZADOKS, R. N.; BOOR, K. J. Development of molecular typing methods for Bacillus spp. And Paenibacillus spp. Isolated from fluid milk produts. Journal of Food Science, Chicago, v. 71, n. 10, p. 50-56, 2006.

ESPEJO, G. G. A.; HERNANDEZ HERRERO, M. M.; JUAN, B.; TRUJILLO, A. J. Inactivation of Bacillus spores inoculated in milk by Ultra High Pressure Homogenization. Food Microbiology, London, v. 44, n. 6, p. 204-210, 2014.

FRANK, J. F.; YOUSEF, A. E. Test for groups of microorganisms. In: WEHR, H. M.; FRANK, J. K. (Ed.). Standard methods for the examination of dairy products. $17^{\text {th }}$ ed. Washington: American Public Health Association, 2004. Chapter 8, Section 8. 090 and 8. 100, p. 239-242.

FUQUAY, J. W.; FOX, P. F.; MCSWEENEY, P. L. H. Encyclopedia of dairy sciences. $2^{\text {th }}$ ed. London: Elsevier, 2011. 1009 p.

HUCK, J. R.; HAMMOND, B. H.; MURPHY, S. C.; WOODCOCK, N. H.; BOOR, K. J. Tracking sporeforming bacterial contaminants in milk fluid milkprocessing systems. Journal of Dairy Science, Madison, v. 90, n. 10, p. 4872-4883, 2007. 
MARTINS, F. H.; GUTH, B. E. C.; PIAZZA, R. M.; LEÃO, S. C.; LUDOVICO, A.; LUDOVICO, M. S.; DAHBI, G.; MARZOA, J.; MORA, A.; BLANCO, J.; PELAYO, J. S. Diversity of Shiga toxin-producing Escherichia coli in sheep flocks of Paraná State, southern Brazil. Veterinary Microbiology, Barcelona, v. 175, n. 1, p. 150-156, 2015.

OSBORNE, C. A.; GALIC, M.; SANGWAN, P.; JANSSEN, P. H. PCR-generated artefact from 16S rRNA gene-specific primers. FEMS Microbiology Letters, Oxford, v. 248, n. 2, p. 183-187, 2005.
PEREIRA，J. R.; TAMANINI， R.; RIOS， E. D.; OLIVEIRA, V. H. S.; YAMAMURA, A. A. M.; BELOTI, V. Microbiota mesophilic aerobic contaminant UHT milk. Revista do Instituto de Laticínios Cândido Tostes, Juiz de Fora, v. 68, n. 394, p. 25-31, 2013.

RIBEIRO JÚNIOR, J. C.; ALCÂNTARA, B. K.; BELOTI, V. Spoilage potential of Paenibacillus sp. in Brazilian raw milk. Ciência Rural, Santa Maria, v. 46, n. 4, p. 637-640, 2016.

SCATAMBURLO, T. M.; YAMAZI, A. K.; CAVICCHIOLI, V. Q.; PIERI, F. A.; NERO, L. A. Spoilage potential of Pseudomonas species isolated from goat milk. Journal of Dairy Science, Madison, v. 98, n. 2, p. 759-764, 2015. 